\title{
Mitigation of the Health and Environmental Impact of Waste Water Treatment Plant in Oman
}

\author{
Ali Abdullah Al Maskari \\ Dr. Adeel H. Suhail
}

\author{
MIDDLE EAST COLLEGE \\ Middle East College
}

\begin{abstract}
Developing countries' experience is a huge gap in the coverage of collection-system and domestic wastewater treatment. Wherever the wastewater treatment facilities are available, they are running below the design standards. This leads to the discharge of pollutants into the natural water bodies and creating a negative impact on the environment and human health as well. Odor nuisance has become a major environmental issue worldwide with increasing public demand for better control of odor emissions from the municipal wastewater treatment facilities. Odor get affects the population directly and there is a trend that more and more peoples are becoming less tolerable with more odor emissions. Bad smell is often an indicator of the public potential health risk.
\end{abstract}

Performance assessment of Haya water treatment plant in Manuma Village has been done. The main objective of this study is to assess the performance of the treatment plant with respect to produce high quality of treated water and reduce odor complaints. Influent and effluent samples were collected at critical treatment steps of the plant and analyzed for chemical, physical and microbial parameters. The study will be used to monitor the Manuma wastewater treatment plant and compare its performance to that one that uses the Sequence Batch Reactor (SBR) process. Study shows that process with wet scrubber technology will be the suitable treatment process to create an environment without any health-related issues, and selecting these alternative treatment facilities with the latest technology will lead to creating high-quality of treated water without any odor issues.

\section{Introduction}

Due to high increasing of Oman Population the waste water generation is keep on increasing.The water resources consumption in Oman increased up to $9.4 \%$ per year and there are more demand for the treated waste water for the re-usage, therefore we need to have some waste water reclamation technology to produce sufficient waste water for the other purposed to fulfill the water requirements in Oman. The ground water salinity level is keep on increasing with increasing population in Oman and the ground water level is going down. (U.S. EPA, 2013).

Agriculture issuing between $60-90 \%$ of surface and groundwater. During the last two decades, the reuse of treated wastewater in agriculture had increased enormously due to the increase of food demanding expansion of agricultural areas putting into consideration that the usage of treated wastewater is currently limited in such a conservative crops list and not extended to all kind of crops as per the regulations and recommendations submitted and delivered by Ministry of Agriculture research center and SQU agriculture college. The shortage of potable water could be partially overcome by use of Treated Wastewater (TWW), (GU. A, 2015).

It is a major challenge to optimize the benefits of treated wastewater as a resource and minimize the negative impacts of its use on human health. Different studies showed an increase of the yield of crops irrigated with treated wastewater (CSDLAC, 2015). 


\section{Journal of Student Research}

Fourth Middle East College Student Research Conference, Muscat, Sultanate of Oman

Wastewater treatment is recommended when considering using wastewater for irrigation. Whatever pathogens are determined in the wastewater we can remove in the primary and secondary treatments with some advanced process technology to produce high quality effluent in order to avoid any health risk to the general public and environment. Some of the treatment can save the farmers who involved and irrigating some food crops by using treated water and consumers of food crops grown using wastewater (Rose, 1999).

Odor nuisance is the major environmental problem with increasing of better control of bad odor emissions from the waste water treatment facilities. Odor affects the public directly and there are more people are becoming less tolerable with abnormal odor emission form the treatment plant.

Bad smell is often regarded as an indicator of the possible public health. So Muscat government is looking into invest in the best odor control technology with cost effective method to prevent and control the odor emissions from the treatment facilities.

Waste water management system in one of the continuous and major challenge in Oman. Implementation of the modern and effectiveness process management solutions must be take it into consideration for the local characteristics and process outlet parameters.

The Sequence Batch Reactor (SBR) process is a modern and latest technology for the sewage treatment of both domestic and industrial waste water. SBR is designed for batch treatment process. This is an excellent selection for the high inflow and more organic load containing sewage water. SBR Plants are so simple mechanical equipment's, more flexible and easy operable. The SBR design is based more current and latest technology.

Sometimes waste water treatment plant is producing low quality treated water due to Old process technology and plant under performance and creating bad odor which could be problem for the environment and human health. Due to waste water treatment plant under performance, the outlet water will be containing high level of BOD, Ecoli, Total Suspended Solids and Total Nitrogen.

The main aim of the study will be focus on the overall performance of a waste water treatment plant and identify factors inhibiting the treatment plant performance and making environmental issues and which is threatening to human health. In line with the main aim, the specific objectives are as below;

1. Assessing process performance of the waste water treatment steps of the plant in relation to the removal of bacterial, physical and chemical quality parameters such as BOD, Total Nitrogen and Total Suspended solids with very maximum reduction level.

2. Identifying the factors which are limiting the process performance in the treatment steps of the waste water treatment plant such as Sludge volume index, dissolved oxygen, Food for Microorganism, Mixed Liquor suspended solids (MLSS) and Sludge age and maintain the optimum level consistently.

3. Selecting the suitable latest technology for the odor control system such as wet chemical scrubber with highest H2S removal efficiency.

\section{Research Methodology}

Sewage treatment technology is the most important factor is affecting the results of the sewage treatment and the product. A suitable and latest processing technology is more important and should be chosen according to the Oman water requirements and specifications.

Environmental impacts and economic benefits are of local importance while selecting the process technology. From the perspective of environmental protection, the construction of the sewage treatment plants generally should not cause irreparable damage to the surrounding environment 
and human health.

Therefore, unsuitable locations include upwind of a city, upstream of an urban water source or in close to the residential areas. After started the operation of the sewage treatment, the effects should be minimized on the particular, the aquaculture at the towns, Moreover the impact should not exceed the local environmental capacity.

The flow chart shown in Figure 1 will be useful to identify all the requirements to select suitable process. For the Selection

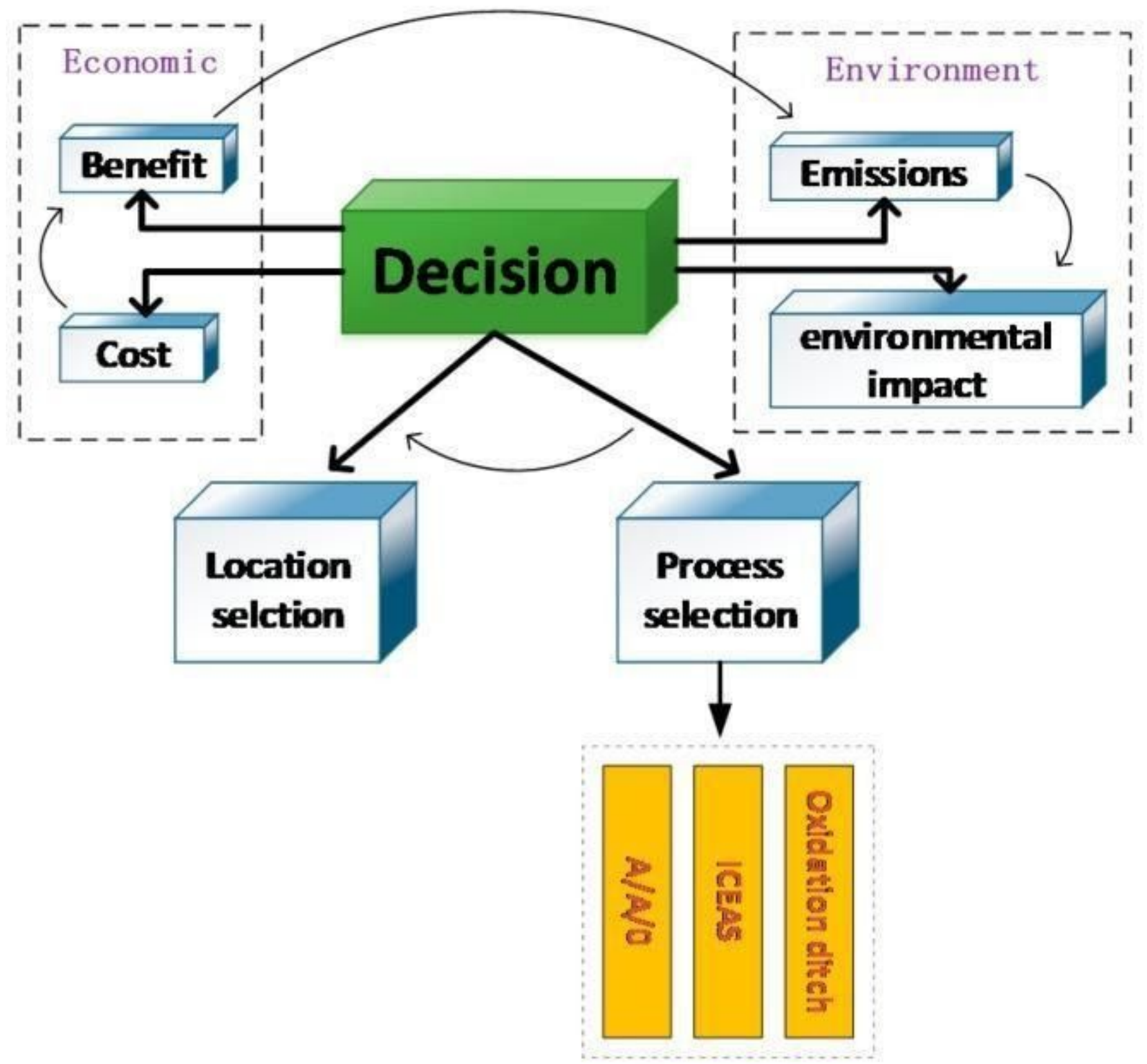

Figure 1. Process selection flowchart.

of suitable process, we have to study and analyze the important

Influent water quantity and characteristics. Also we have to meet customer requirements and Environmental law and Concession agreement with Oman Government. 
The Sequence batch reactor (SBR) is a batch process which includes filling, mixing, settling and decanting process with activated sludge maintaining in the aeration basin. The process involved equalization of sewage and aeration and clarification of suspended solids.

To optimize the process performance, we have to more SBR basin put into the operation to handle large volume of sewage. SBR process will be more successful for the municipal and industrial waste water sources, it will be more suitable for the water treatment application characterized by low or intermittent flow conditions.

\section{SBR Process characteristic}

SBR process is a kind of Activated sludge process, but they are different from the activated sludge process, because all of the process steps will be happening in the single tank or basin whereas the conventional basin required multiple basins.

The sequencing batch reactor (SBR) is a fill-and draw activated sludge system for wastewater treatment. In this system, wastewater is added to a single "batch" reactor, treated to remove undesirable components, and then discharged.

Equalization, aeration, and clarification can all be achieved using a single batch reactor. To optimize the performance of the system, two or more batch reactors are used in a predetermined sequence of operations.

\section{Basic Treatment Process}

The operation of the SBR is based on a fill and draw type process, which consist of 4 steps
1. Filling
2. Aeration or Reaction
3. Settling
4. Decanting

\section{Filling Phase}

During the filing phase SBR Basins will receive the influent waste water. The influent waste water will bring lot of food for the microorganism in the activated sludge. Then the microbial reaction will take place in the SBR Basin. 


\section{Journal of Student Research}

Fourth Middle East College Student Research Conference, Muscat, Sultanate of Oman

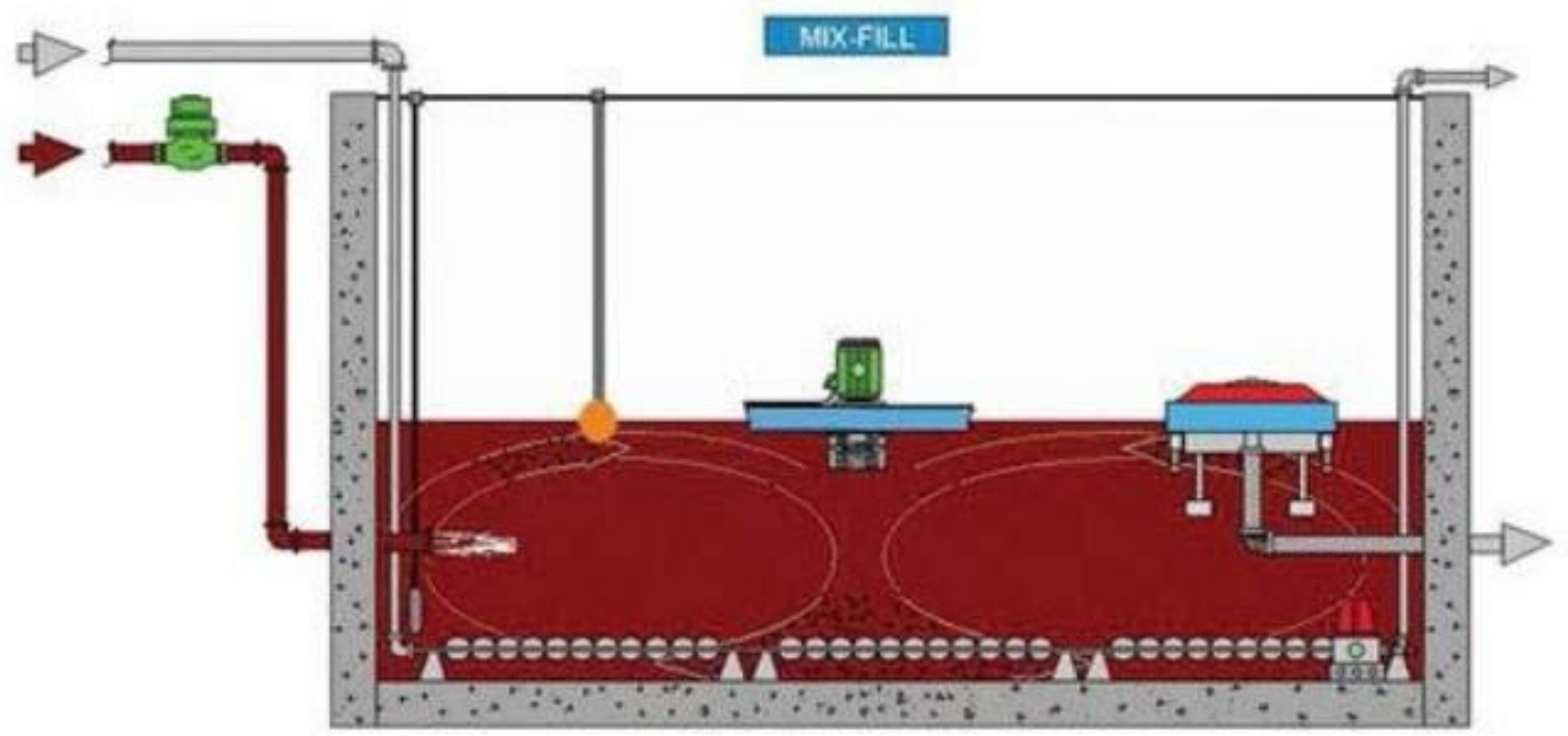

Figure 2. Filling Phase

\section{Reaction Phase}

During this process phase no influent water will enter into the SBR Basin. Only Aerators and mechanical mixer will be running condition. Because we should maintain organic load in the particular basin, then only there will be large quantity of organic load reduction.

During this process most of the Carbonaceous BOD removal will take place. Further extended aeration will be permitted to enhance the de nitrification process. Some additional Phosphorous will release during this process.

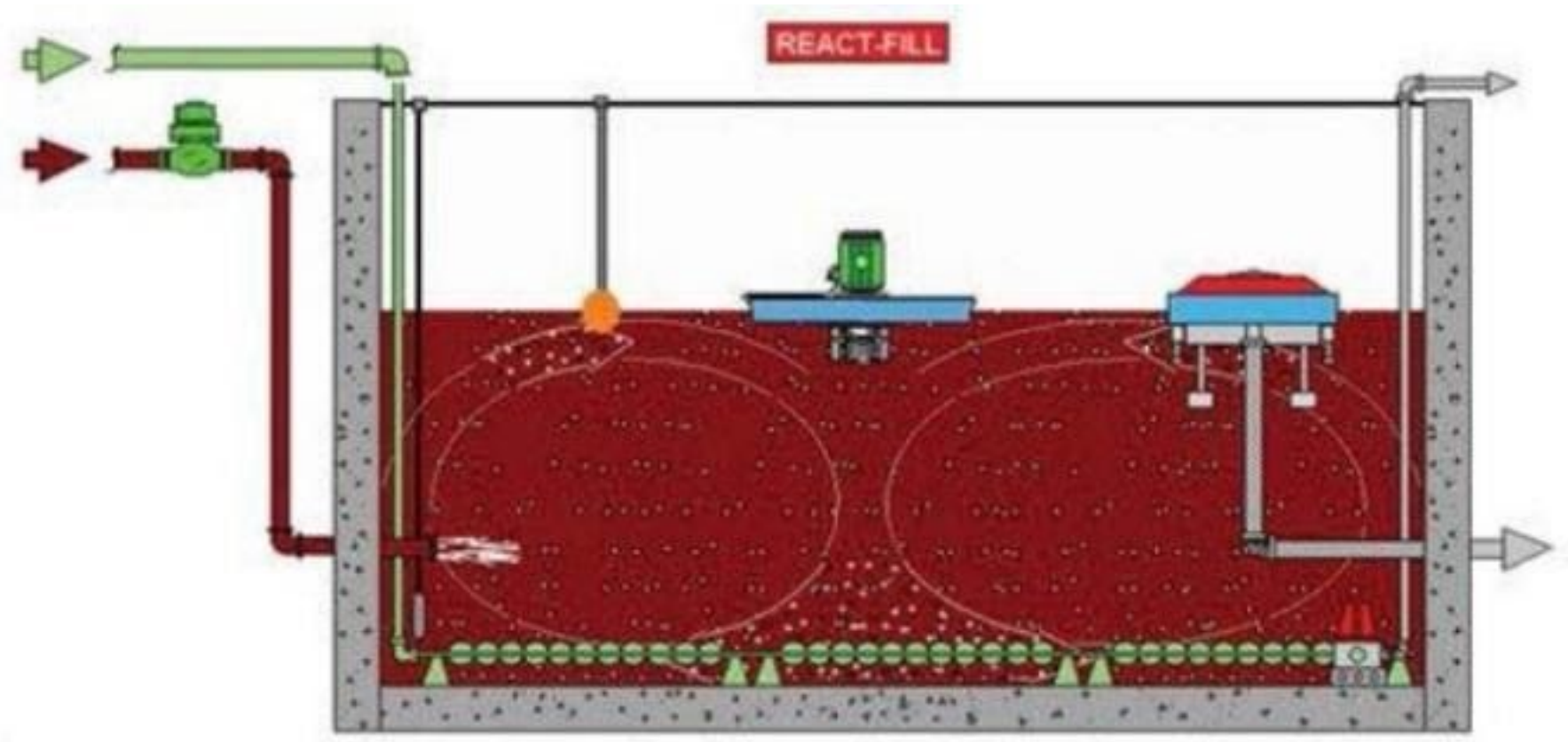

Figure 3. Reaction Phase 


\section{Journal of Student Research}

\section{Settling Phase}

During the process phase, activated sludge and influent are allowed to settle in the stable condition. Influent waste water should not enter into the SBR basin and aerator and mechanical mixer are should be off condition.

The activated sludge is allow settling as a flocculent mass and it will make a separate layer as a supernatant layer and settled bio mass layer. The sludge mass is called Sludge blanket.

This settling phase is very critical, because if the solids are not properly settled then the suspended particles will be carryover in the decanting water. It will affect the treated effluent quality.

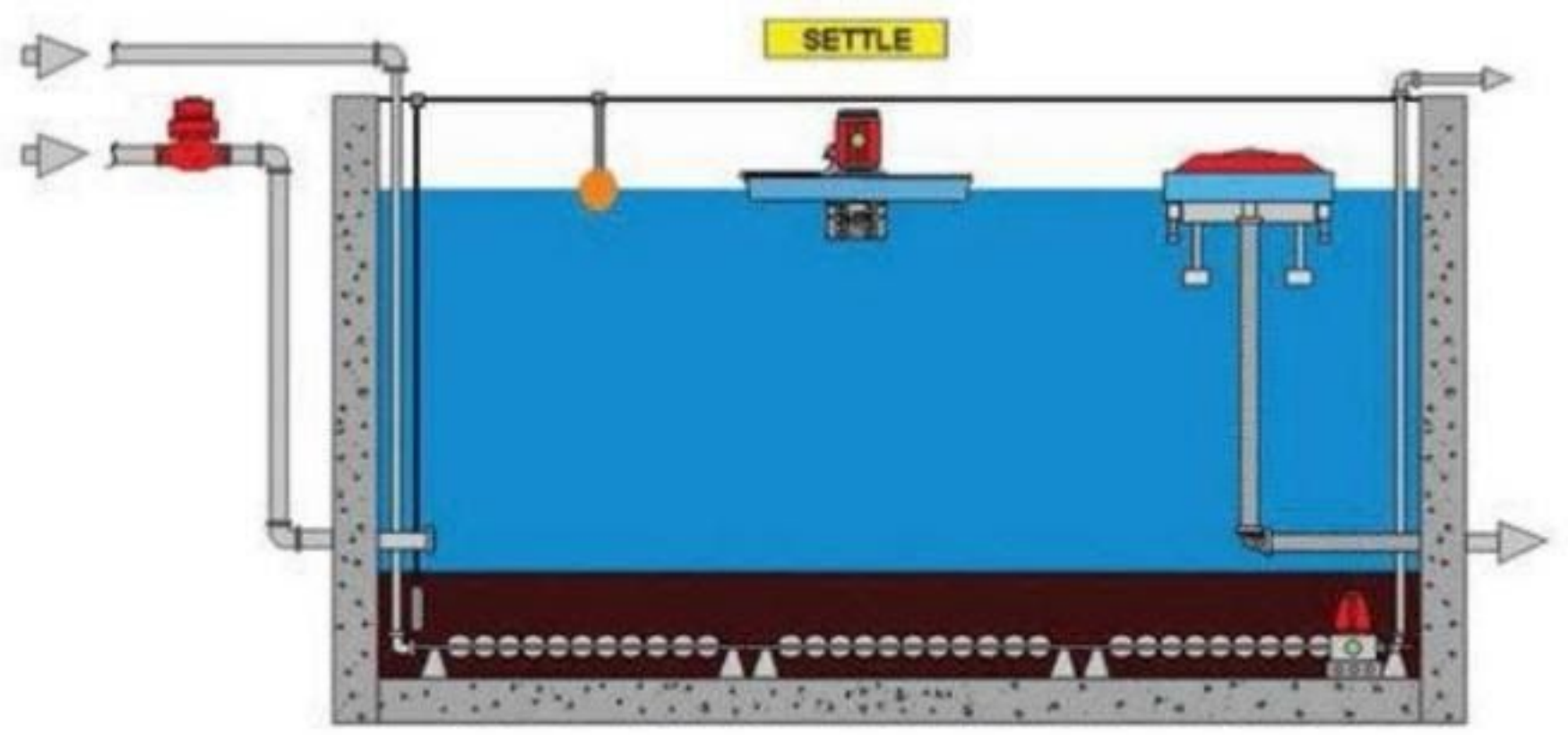

Figure 4. Settling Phase

\section{Decanting}

During this phase the clear supernatant liquid will be transferred to the next phase by using the decanter mechanism. 


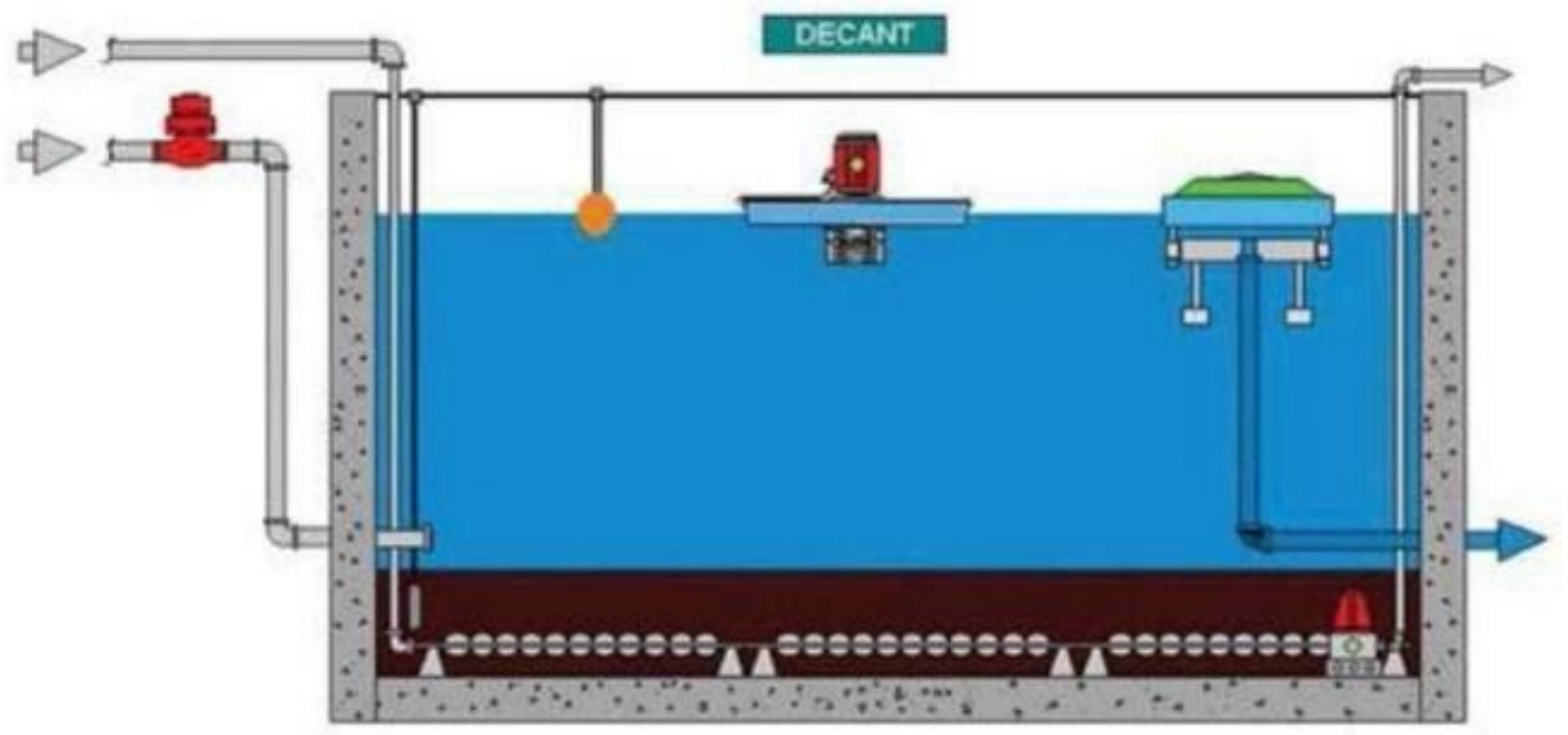

Figure 5. Decanting Phase

\section{SBR Advantages}

- All the Process (Primary \& Secondary) is happening in the single SBR tank.

- It has more operating flexibility and monitoring and control.

- Less Operational problem

- Less capital cost

- Very high quality effluent

\section{SBR Disadvantages}

- It is required long time to treat the sewage for the larger volume plants.

- Required more maintenance due to more instrumentations and control.

\section{MBR Process}




\section{The membrane is immersed directly into the water to be treated}

\section{Light suction draws water through the membrane pores}

Concentrate stream is continuously recirculated and sent to anoxic tank.

\section{Daily membrane light cleaning through \\ - Backpulse \\ - Relaxation / Aeration}

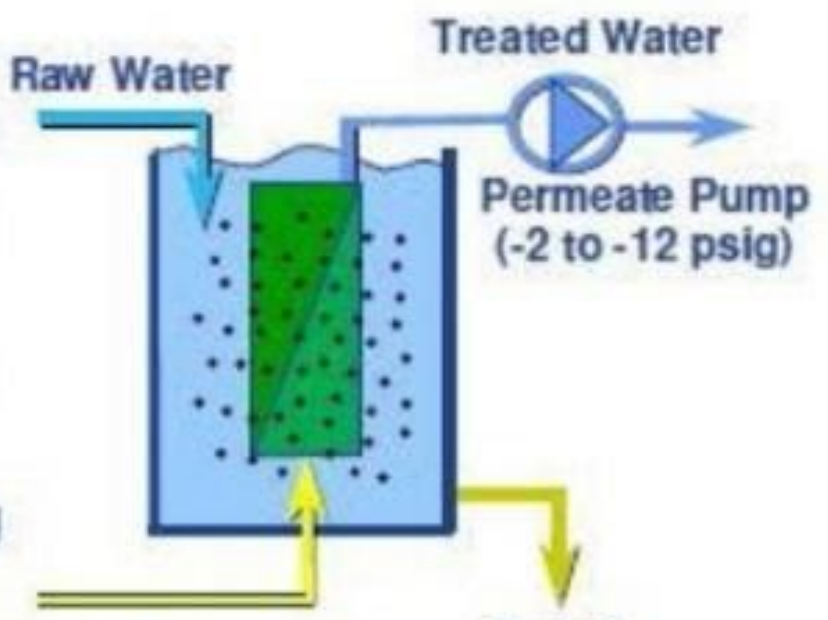

Air

Reject

Figure 6.

Membrane Bio Reactors is a combined conventional biological treatment process with membrane filtration to remove organic loads and suspended solids, along with nutrient removal.

\section{Basic Ancillary Equipment to operate}

\section{Membrane Air Scour Blower}

The membrane air score blower will be operated continuously along with influent flow coming to maintain dissolved oxygen in the MBR basin.

\section{Permeate Pump}

Each membrane train will have a individual permeate pump. The permeate pump will create vacuum to draw clean water through the membrane and discharge it to the dis infection phase.

\section{Chemical Pump}

Chemical pump will be used to inject the chemical during the cleaning cycle. Generally this pump like a diaphragm type with chemical proof type.

\section{RAS Pump}

The RAS pump will draw mixed liquor from the membrane tanks discharge it back to the aeration tank. RAS pumps will pump mixed liquor at 3-4 times the flow rate of the permeate.

\section{MBR Advantages}

1. A Significant advantage of the MBR process is the mixed liquor are completely retained in the bio reactor. It means the solids retention time in the bio rector can be controlled independently from the Hydraulic retention time.

2. ave a smaller footprint 
3. Provide better pre treatment

\section{MBR Disadvantages}

1. Relatively expensive to install and operate

2. Required high energy

3. Frequent fouling of Membranes

4. More chemical consumption for the Membrane cleaning

\section{Experimental Procedures}

Collect the operation data from Sewage treatment plants has generated some useful operational control strategies. All the analytical result will help us to study and control the process. Data for three months were collected and analyzed on the system efficiency and performance.

Raw Sewage Analysis Report, SBR Outlet Analysis Report, and SBR Outlet Analysis Report were analyzed for this period. The Variability of treatment effectiveness needs to be checked in every process treatment steps to STP Efficiency by analyzing all the important process parameters. It needs to collect the samples from all the stages on daily basis and study the process performance compare to design standards.

\section{Calculation for the BOD Removal Efficiency}

BOD Removal Efficiency $=($ Influent BOD - Effluent BOD) / Influent BOD X 100

For Example on 04/12/2018 BOD Values

Influent BOD - $260 \mathrm{mg} / \mathrm{lit}$

Effluent BOD - $4 \mathrm{mg} / \mathrm{lit}$

BOD Removal Efficiency $=(260-4) / 260$ X 100

BOD Removal Efficiency $=98.46 \%$

\section{Calculation for the Total Nitrogen Removal Efficiency}

For Example on 04/12/2018 Total Nitrogen Values

Influent Total Nitrogen - 58.06 mg/lit

Effluent Total Nitrogen - $0.25 \mathrm{mg} / \mathrm{lit}$

Total Nitrogen Removal Efficiency = (Influent Total Nitrogen - Effluent Total Nitrogen) / Influent Total Nitrogen X 100

Total Nitrogen Removal Efficiency $=(58.06-0.25) / 58.06$ X 100

Total Nitrogen Removal Efficiency $=99.56 \%$

\section{Calculation for Total Suspended Solids Removal Efficiency}

For Example on 04/12/2018 Total Suspended Solids Values 
Influent Total Suspended Solids - $266 \mathrm{mg} / \mathrm{lit}$

Effluent Total Suspended Solids - $5 \mathrm{mg} / \mathrm{lit}$

Total Suspended Solids Removal Efficiency $=($ Influent TSS - Effluent TSS) / Influent TSS X 100

Total Suspended Solids Removal Efficiency $=(266-5) / 266$ X 100

Total Suspended Solids Removal Efficiency $=98.12 \%$

\section{Results}

\section{Evaluating the Treatment Process}

The STP Treatment process has to be evaluated with other STP Plants. For project I have get the data from other STP Plants and evaluate with running STP Process parameters. Performance limiting factors relating to operations included the lack of application of concepts and testing to achieve process control, inadequate process control testing and inaccurate performance monitoring with Online monitoring facilities.

The following Important Process parameters are affecting the SBR process

\section{Sludge Age:}

The sludge age is the amount of time, in days that solids or bacteria under aerating condition. Sludge Age is used to maintain correct amount of bacteria in the aeration basin.

It is a useful test that indicates changes in the sludge settling characteristics and quality. Sludge Age-The concentration of the activated sludge solids and the condition of those biological solids determines the effectiveness of an activated sludge process. Too few or too many organisms in a system will cause operational control problems, reducing treatment plant efficiency and causing an added load on the receiving waters.

Sludge Age $=$ pounds of suspended solids in the aeration tanks = MLSS (mg/lit) $\mathrm{x}$ Volume of aeration tanks in Million Gallon x 8.34 pounds /gallons of waste water.

SBR Process Sludge Age to be maintained 8 to 12 days.

\section{Sludge Volume Index - SVI}

The sludge volume index of an activated sludge process is used to measure the mixed liquor suspended solids (Milligram per liter) concentration in the aeration basin to study the activated sludge characteristics.

The SVI is the volume of mixed liquor suspended solids is divided by the density of the mixed liquor.

SVI = Volume of settled solids (ml) after 30 minutes / density of Mixed liquor suspended solids (g/l)

SBR Process SVI to be maintained 120 - 140

\section{Food for microorganism - FM ratio}

Food to microorganism is a measurement of food entering into the activated sludge process and the 


\section{Journal of Student Research}

Fourth Middle East College Student Research Conference, Muscat, Sultanate of Oman

microorganism in the aeration tank. The F/M ratio may vary depends on seasonal basis, high $\mathrm{F} / \mathrm{M}$ will be maintained in summer and lower F/M Ratio will be maintained during winter.

The Food \Mass or the Food \Microorganisms ratio commonly referred to as $F \backslash M$ is based upon the ratio of food fed to the microorganisms each day to the mass of microorganisms held under aeration. Analysis on characteristics and design parameters of conventional activated sludge system and also calculate the production of gas by plant as well as variation of plant monitoring parameters which will increase the efficiency of plant by controlling them.

F/M Ratio = Pounds of BOD in the aeration tanks/ Pounds of MLVSS in the aeration tank.

F/M Ratio to be maintained in SBR 0.2 to $0.4 \mathrm{mg}$.

\section{Mixed Liquor suspended solids - MLSS}

The mixed liquor suspended solids is the amount of microorganism (bacteria) which is involving in the activated sludge process.

MLSS to be maintained in SBR 2000 to $3000 \mathrm{mg} / \mathrm{lit}$

\section{Hydraulic Retention time - HRT}

The Hydraulic retention time of an aeration tank is the amount of time in hours for waste water passes through aeration tank.

The changes in HRT will affect the microbial activity.

HRT $(\mathrm{hr})=$ Volume of aeration tank, gallons / flow rate gph

HRT to be maintained 4 to 6 hours.

All the above parameters will be monitored continuously on daily basis to study the process condition and it will use to adjust and maintain the process whenever required.

Some design related factors were identified during the evaluations. However, none of the evaluations determined that any of the design limiting factors were serious enough, such that the plants could not produce the desired quality effluent under current loadings, if minor modifications and proper process control were applied to the existing facilities.

Some performance limiting factors are relating to design included limited on-site sludge storage capacity, excessive secondary clarifier hydraulic loading,

Lack of process flexibility, hydraulic surging, poor process controllability. Limited on-site sludge storage was alleviated by the ability to haul sludge to off-site storage.

\section{Reliability of Process}

Treatment plant reliability can be defined as the probability that a system can meet established performance criteria consistently over extended periods of time. In the treatment plant facility reliability is core important where the critical water quality parameters have to be maintained such as in reuse applications.

For the process reliability have collected one year SBR Plant data from the other STP plant and cross check with existing MBR Plant data and found that the SBR process outlet quality will be 
higher than SBR Plant quality.

SBR Plant outlet quality will be more consistency than the MBR treated water quality and its meeting the Oman environment requirement.

For the further improvements on line monitoring of critical parameters such as total organic carbon (TOC), turbidity, and dissolved oxygen would be recommended for building a data base and for improving process control.

Chlorine residual monitoring is useful for dosage control in the dis infection process to control $\mathrm{E}$ Coli bacteria and $\mathrm{pH}$ monitoring is assists in controlling nitrification process in the aeration systems. Important factors in the process selection and design are treatment plant performance and reliability in meeting plant permit requirements.

From the above analysis report is has been proven that the residual chlorine level was maintained more than $0.5 \mathrm{ppm}$. So this level of chlorine will kill all the bacteria from the treated water and the E Coli results are shown as $10-40$ within the limit.

\section{Process Validation}

Process validation is a critical component of treated process management because it ensures that the required water quality objectives will be achieved. Validation and monitoring assess the overall performance of the system and compliance with the overall water quality objectives. The overall water quality meets with the Oman requirement as per the concession with Muscat Government.

\section{Quality treated water Production}

SBR Process outlet water quality will meet all the below requirements without fail in a consistent way. So SBR process will be more suitable process for the waste water treatment plant to achieve the treated water quality than MBR Process.

\section{Achieve the process parameters as per design}

The SBR treatment plant will be achieved all the process parameters as per the design and Oman requirements. All the Important process parameters are evaluated in the above study and all parameters are complying with Oman Environment standards and regulations.

\section{Discussion}

The Discussion should explain the significance of the results and place them into a broader context. It should not be redundant with the Results section. This section may contain subheadings and can in some cases be combined with the Results section. Times new roman 9 pt. The Discussion should explain the significance of the results and place them into a broader context. It should not be redundant with the Results section. This section may contain subheadings and can in some

From the above analysis SBR Process Plant will produce very good quality of treated effluent since most parameters showed compliance with MECA standards. The removal efficiency will be achieved minimum at SBR plant for TSS, TN and BOD are $98.12 \%, 99.56 \%$ and $98.46 \%$ respectively.

The wet chemical scrubber Odor Control system will be achieved 99.39\% efficiency.

SBR system is more flexible and easy to operate, so SBR process will produce high quality effluent consistently and it will safe guard the environment and human health. 
SBR plant should come with Programmable Logic Controller (PLC) or Supervisory Control and Data Acquisition (SCADA) to monitor the process changes closely. Also, the SBR plant should have online sensors for the Dissolved Oxygen, PH, Total Organic Carbon, Ammonia and MLSS and all these analyzer readings are to be configured with Data Acquisition system to monitor all the parameters deviation.

In addition, Wet Chemical Scrubber should come with $\mathrm{PH}$ analyzer and Oxidation Reduction Potential (ORP) to minimize the chemical consumption.

Doing pumps should be operated in automatically with corresponding to the analyzer readings set point and it should be configured with Data Acquisition system and Wet Scrubber should have the inspection class to monitor the spray nozzle flow type and circulation water color.

\section{Conclusion}

Oman is one of the water scarcity facing country, which requires innovative ways to bridge the existing water supply gap and meet national industrial, domestic and agriculture water needs.

Waste water is an important resource that is still ignored and underutilized in Oman. To improve their resources within the border sustainable country development framework, research should explore appropriate and feasible options for reusing waste water especially in Oman.

Waste water treatment goals should mainly focus on the E Coli, suspended solids and BOD removal which will give acceptable quality for reuse in irrigation and industrial process. This study is help to select the suitable process which have the ability to achieve the future requirements of treated water permissible limits. In addition, from this study the following recommendations are to be implemented

1. We have to select alternative treatment facilities with latest technology to produce high quality of treated water without any odor issues.

2. Continuously strengthening and implementation of integral pollution prevention and control licensing mechanism like ISO 14001 certification.

3. As per the above study Sequence batch reactor with wet scrubber technology will be the suitable treatment process to produce environment without any health related issues.

4. Need to extend water quality monitoring in all the stages to achieve high quality treated effluent.

5. Need to implement environmental impact awareness of large volume of new irrigation projects in Oman.

\section{Acknowledgements}

The authors want to acknowledge the mechanical engineering department at Middle East College for providing the full support which realized this research

\section{References}

CSDLAC (2015) Pomponna Virus Study Final Report. County Sanitation Districts of Los Angeles Country, Whittier, CA.

Gu A. (2015). Endocrine Disrupotors: What Are We Facing. Waterscapes, Technical Publication of the water group of HDR, Vol.16, No. 1,pp. 8-9,OmanNE.

Haya Water (2018) Haya water [online] available online from 


\section{Journal of Student Research}

Fourth Middle East College Student Research Conference, Muscat, Sultanate of Oman

$<$ https:haya.om/en/Pages/Home.aspx> [Nov,2018].

Oman Water and Waste water Management, export.gov web site, Available online from <https://www.export.gov/article?id=Oman-Water-and-Wastewater-Management> [April ,2017].

U.S. EPA (2013). Water Quality Standards Handbook, 2nd ed. EPA-823-B-94-005a. 